rent monograph holdings, and will evaluate whether the TALON Cooperative Acquisitions Program has had a measurable effect on the collections of participating libraries.

\section{NEWS NOTES}

- The Center for Research Libraries, Chicago, has accepted ownership and managerial control of the Foreign Newspaper Microfilm Project (FNMP) from the Association of Research Libraries, effective January 1. The project, originating at Harvard in 1938, is designed to maintain a pool of current foreign newspaper titles on microfilm and has been housed at the Center since 1956. CRL's absorption of the proj- ect provides for all present participants, whether or not members of the Center, to continue to take part in the project; however, no new nonCRL members may participate without first becoming Center members.

- The U.S. Office of Foreign Assets ConTROL has lifted its ban on the importation of single copies of published materials from Cuba, Vietnam, North Korea, and Cambodia, according to a January issue of the Federal Register. The Customs Service can now release to individual or institutional addressees any books, newspapers, magazines, films, phonograph records, microfilm, microfiche, posters, and similar materials published in these countries.

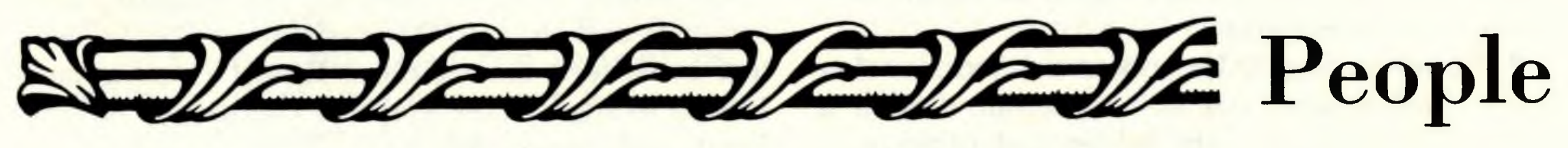

PROFILES

Don L. Bosseau, university librarian at the University of Hawaii, has been named librarian of San Diego State University effective this summer. He has also served as director of libraries at Emory University and at the University of Texas at El Paso. From 1966 to 1972 he worked at the University of California, San Diego, as assistant university librarian and head of computer applications.

Prior to his work at UCSD, Bosseau was assistant librarian and research associate at Gen-

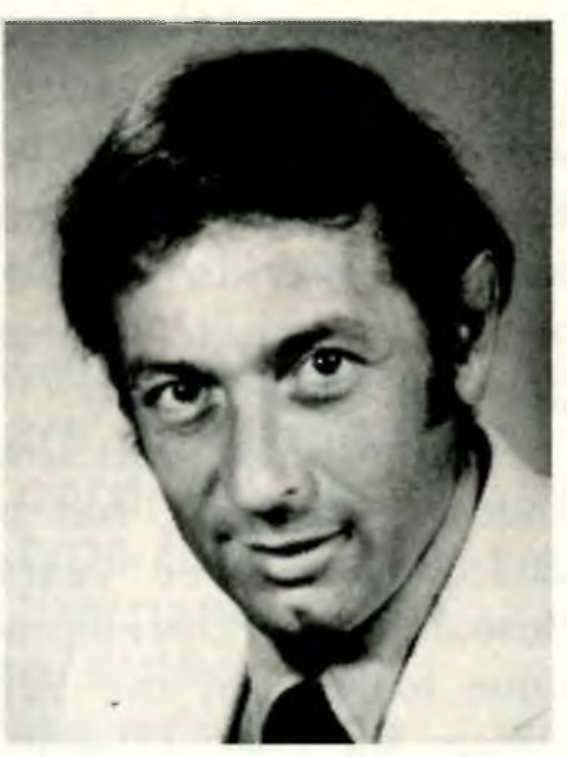

Don L. Bosseau eral Atomic in La Jolla and a research engineer at Allis-Chalmers Nuclear Division in Milwaukee. He holds a master's in engineering from the University of Kansas and an MLS from the University of Hawaii.

In five years as chief administrator for the collections at the Manoa campus in Honolulu, Bosseau has been actively involved in reorganizing the library's structure to accommodate new computer systems.

Stevens W. Hilyakd has been appointed university librarian at the University of Southern Maine, effective July 1. Hilyard was most recently director of the library at Pittsburg State University, Kansas, from 1976 to 1982 . Prior to that he was college librarian at New England College (1966-1976), assistant librarian at Grand Valley State Colleges (1965-1966), and administra- tive assistant to the librarian at Bowdoin College (1962-1963).

Hilyard recently completed most of the requirements for a doctorate in the administration of educational media and technology at Boston University, and has begun work on a dissertation on "educational, experiential, and personality characteristics of academic educational media directors." His MLS is from the University of Michigan.

$\mathrm{He}$ is also involved in consulting, with experience in the implementation of technology and building planning and design.

Bruce M. Hurlbert has been named director of library services at Lycoming College, Williamsport, Pennsylvania, effective February 1. Prior to this appointment he was assistant director of libraries for administration at Virginia Commonwealth University, where he had also served as assistant director for the academic campus.

From 1968 to 1972 he held several positions at Florida Atlantic University, the most recent being that of assistant director for

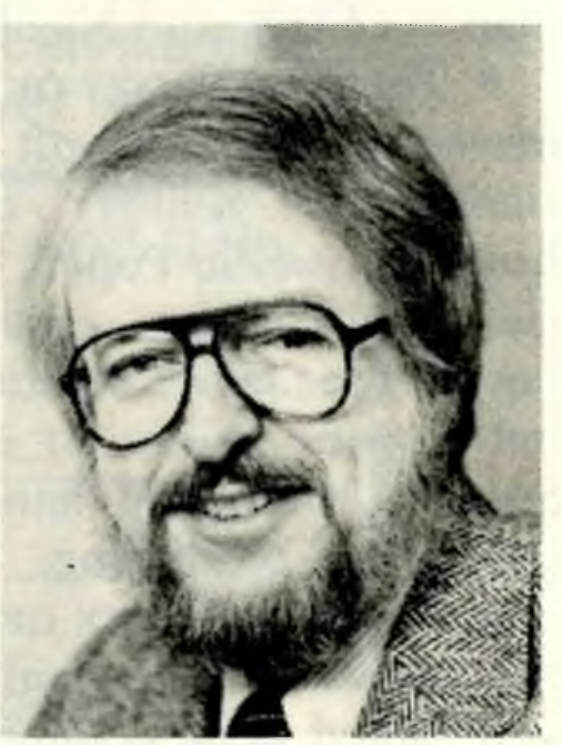

Bruce M. Hurlbert technical services.

Hurlbert received an MLS from Florida State University in 1968.

JoHN G. JAFFE has been named director of libraries at Sweet Briar College, Virginia. Since 1979 Jaffe has been acquisitions librarian, rare 
books librarian, and archivist at Sweet Briar. Prior to that he held similar positions at Bryn Mawr College Library, Pennsylvania.

Jaffe received an MLS from Villanova University in 1974, as well as a master's in English in 1971.

VIRGINIA LACY Jones has been named the first director of the new Atlanta University Center's Robert W. Woodruff Library. Since 1967 Jones has participated in the planning and assessment of library needs in the Atlanta University Center, and she now will head the planning, organizing, and directing of the library's holdings and professional services of the consortium institutions in the Center-wide Woodruff Library facility.

In accepting the appointment, she relinquished her duties as

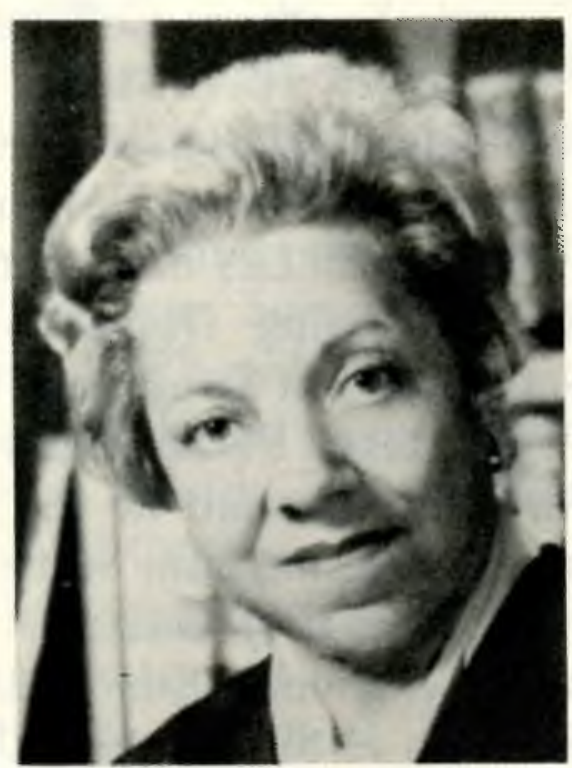

Virginia Lacy Jones dean of the Atlanta University Graduate School of Library and Information Studies, a post she has held since 1945. She came to the university in 1939 and joined the teaching staff of the library school when it opened in 1941.

Jones holds two bachelor's degrees from the Hampton Institute, an MLS from the University of Chicago, and honorary degrees from the University of Michigan and Bishop College. She has received both the ALA Melvil Dewey Award and the Joseph W. Lippincott Award, and has served as editorial consultant for Library Journal.

Alberta Gayle Mayberry has been named director of the Zale Library at Bishop College, Dallas, effective February 1. She came to Bishop from the position of public services librarian/liaison for the Industrial Education Division of Houston Community College. Mayberry received her MLS from Atlanta University in 1971, after which she was appointed teacher education librarian at Texas Southern University.

She served as a Mellon-ACRL Library

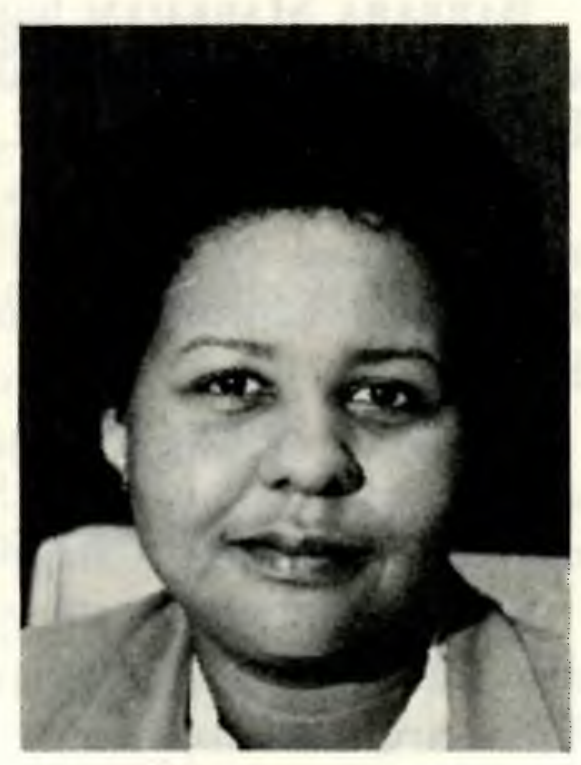

Alberta Mayberry
Administration Intern in 1976-1977 at Emory University, where she assisted in the development of collection development guidelines and other policies. In 1978 she took a position with Ahmadu Bello University in
Zaria, Nigeria, where she served as coordinator of campus services and taught courses in the management of LRC facilities.

Kathleen J. Moretto, formerly assistant director of the Music Library at Yale University, has been named director of the Franklin and Marshall College Library, Lancaster, Pennsylvania, effective in April. Her previous library experience includes consulting work for PALINET and positions as librarian of the Notre Dame International School in Rome, assistant music librarian at SUNY-Buffalo, and head of technical services at the Philadelphia College of the Per-

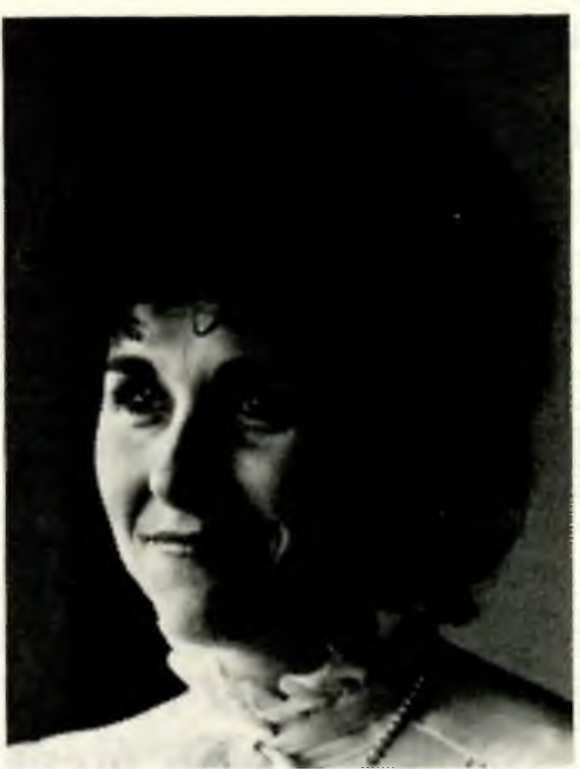

Kathleen Moretto forming Arts.

Moretto holds a master's degree in musicology from the University of Pennsylvania (1977), an MLS from Drexel University (1968), and a bachelor's degree in music from the University of Pennsylvania.

She was a Council on Library Resources Academic Library Management Intern at the University of North Carolina at Chapel Hill in 1980-1981. She currently serves on the board of directors of the Music Library Association as a member-at-large, and has been a member of the American Musicological Society's Committee on the International Inventory of Musical Sources since 1975 .

Doyle Picketr, formerly vice president of marketing for the Baker \& Taylor Company, has been appointed president of Unipub in New York. Pickett was responsible for developing the Baker \& Taylor approval plan in 1969 and since 1976 has focused his attention on the needs of academic libraries in particular. In 1978 he worked out the scope and ground rules with ACRL for the Academic or Research Librarian of the Year Award, the first of which was presented at

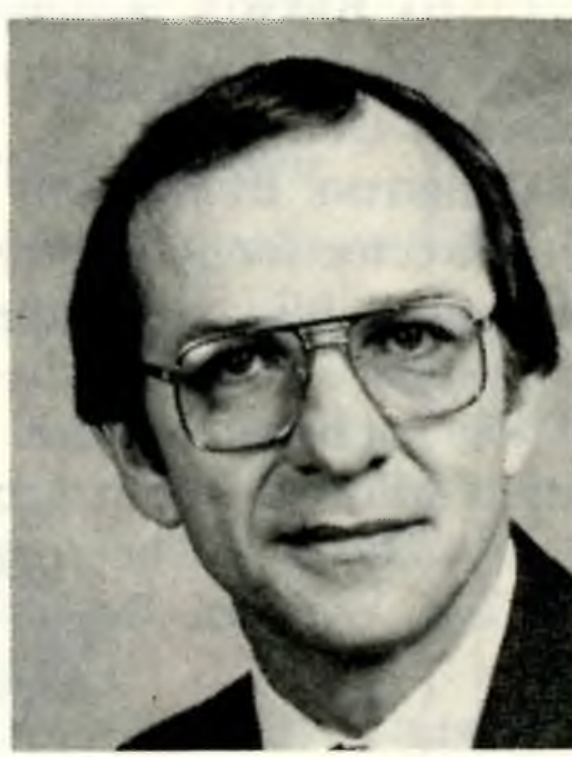

Doyle Pickett the First ACRL National Conference in Boston, and has represented Baker \& Taylor in the presentation of the award ever since.

In 1977 Pickett co-authored (with Kathleen McCullough) an Oryx Press monograph, Ap- 
proval Plans and Academic Libraries: An Interpretative Survey. In 1980-1981 he was on the advisory board of Technicalities and still serves on the advisory board of the Society of Logistics Engineers.

As president of Unipub he will continue to focus on the needs of academic and special libraries.

Peggy Porter, formerly librarian at Chatham College, has been named head librarian of the Hunt Library, Carnegie-Mellon University, Pittsburgh. Prior to taking her position at Chatham in 1977, Porter spent five years as coordinator of information services at Allegheny County Community College.

She received a bachelor's degree in English literature in 1962 and an MLS in 1965, both from the University of Texas at Austin.

Porter has been president of the Pennsylvania Library Association's College Research Division.

\section{APPOINTMENTS}

Katherine J. Adams has been appointed assistant head librarian and archivist of the Barker Texas History Center at the Perry-Castañeda Library, the University of Texas at Austin.

Anthony J. Amodeo has assumed the position of Illinois cooperative conservation librarian at Morris Library, Southern Illinois University, Carbondale.

John William BeEcher is now head of public services of the St. Paul Campus Libraries, University of Minnesota Libraries, Twin Cities.

ARneice Hiluard Bowen is now catalog librarian at the D.H. Hill Library of North Carolina State University, Raleigh.

LISA C. Browar has joined the staff of the Vassar College Library, Poughkeepsie, New York, as curator of rare books and manuscripts.

LINDA BRYSON is now consultant for Educational Information Services at the Colorado State Library, Denver.

Christine Burroughs has been named assistant director for public services at the University of Georgia Libraries, Athens.

Sandra C. Dow has been appointed to the staff of the Taubman Medical Library at The University of Michigan, Ann Arbor.

ANN Drain has been appointed acting director of Case Western Reserve Libraries, Cleveland, Ohio.

Earle C. Ferguson has been appointed associate director of libraries for the University of Manitoba, Winnipeg.

NANCY GibBs has been appointed humanities cataloging librarian at the Ralph Brown Draughon Library, Auburn University, Alabama.

Barbara GLendenning has been named reference librarian at California State University Dominguez Hills, Carson.
Peggy Grossman is the new information science librarian at the University of Texas at Austin.

Peter Haikalis is now assistant director for readers services at San Francisco State University Library, California.

Forrest A. Hall is now reference librarian at California State University Dominguez Hills, Carson.

JULIE HANSEN has joined the reference staff at Georgia Southern College Library, Statesboro.

Carolyn Havens has been appointed serials cataloging librarian at the Ralph Brown Draughon Library of Auburn University, Alabama.

BETH Holley has joined the staff of the Original Cataloging Department at the University of Southwestern Louisiana, Lafayette.

JoNATHAN F. HuSBand has been named reader services librarian at the Henry Whittemore Library, Framingham State College, Massachusetts.

Brenda L. Johnson is now head of the Document Delivery Services/New Jersey Reference Services at the Rutgers University Libraries, New Brunswick, New Jersey.

ScoTT Kass is the new Instructional Services librarian at Florida International University Library, Bay Vista Campus.

JOHN KUPERSMITH has been appointed assistant for public services programs at the PerryCastañeda Library, the University of Texas at Austin.

BruCe EARLe Langdon has been appointed departmental director of Wilson Library, University of Minnesota Libraries-Twin Cities.

Gerald Leibowitz has been appointed mediareference librarian at Nassau Community College, Garden City, New York.

Mary C. MaIden has assumed the position of science reference librarian at the University of Georgia Science Library, Athens.

Mark MaIRE has been appointed reference librarian at Monmouth College, Illinois.

Barbara Markham has been appointed associate director for technical services at the Florida Institute of Technology Library, Melbourne.

Loretta K. Mershon has been appointed assistant head of the Serials Department of the D.H. Hill Library at North Carolina University, Raleigh.

Barbara Burns Moran has joined the faculty of the School of Library Science at the University of North Carolina, Chapel Hill.

Susan Neuman is now librarian for the Graduate School of Business at the University of Pittsburgh, Pennsylvania.

Diane S. Nixon has been appointed serials acquisitions librarian at the University of California, Santa Barbara.

Alan Nourie was appointed Humanities Department head at the Ralph Brown Draughon Library of Auburn University, Alabama.

JOHANNA OLSON has been appointed reference 
librarian at the Bakersfield Library of California State College.

R. Bruce Parham has been appointed University archivist at California State University Dominguez Hills, Carson.

Deborah Raikes has been appointed personnel officer at the University of Delaware Library, Newark.

Cynthia Rice has been named Louisiana Room reference librarian at the University of Southwestern Louisiana, Lafayette.

John J. Riemer has been appointed serials cataloger at the University of Georgia Libraries, Athens.

Fred W. Roper has been named associate dean of the School of Library Science at the University of North Carolina, Chapel Hill.

Dorothy Rosenthal is now head of the Circulation Department of the Florida International University Library, Tamiami Campus, Miami.

GARY Ross has been appointed automated cataloging/OCLC coordinator at the PerryCastaneda Library of the University of Texas at Austin.

Reiner Schaeffer has been appointed director of the U.S. Air Force Academy Library, Colorado.

LORRAINe SEbo has been appointed government documents librarian at Stanford University, California.

Renata V. Shaw has been named assistant chief of the Prints and Photographs Division of the Library of Congress.

Richard N. Shaw has been appointed nonprint services librarian at the University of the South, Sewanee, Tennessee.

Patsy Haley Stann has been appointed interim director of the Continuing Library Education Network and Exchange, Inc. (CLENE), Washington.

JANET SWANBECK has accepted the position of head of the Documents Division at Texas A\&M University Library, College Station.

Karen SwITT is the new business reference librarian at Florida International University, Tamiami Campus, Miami.

JoHn TONGATE has been appointed head librarian of the Reference Services Department, University of Texas at Austin.

SUSAN M. UNGER has been appointed assistant librarian for technical services at the Jennie King Mellon Library, Chatham College, Pittsburgh.

PhILlip White has been appointed reference librarian for social sciences at the University of Texas, Austin.

E. Louisa Worthington is now reference librarian for social sciences, humanities, and health sciences at the O'Leary Library, University of Lowell, Massachusetts.

Patricia L. Wright has been named associate director of the Sweet Briar College Library, Virginia.

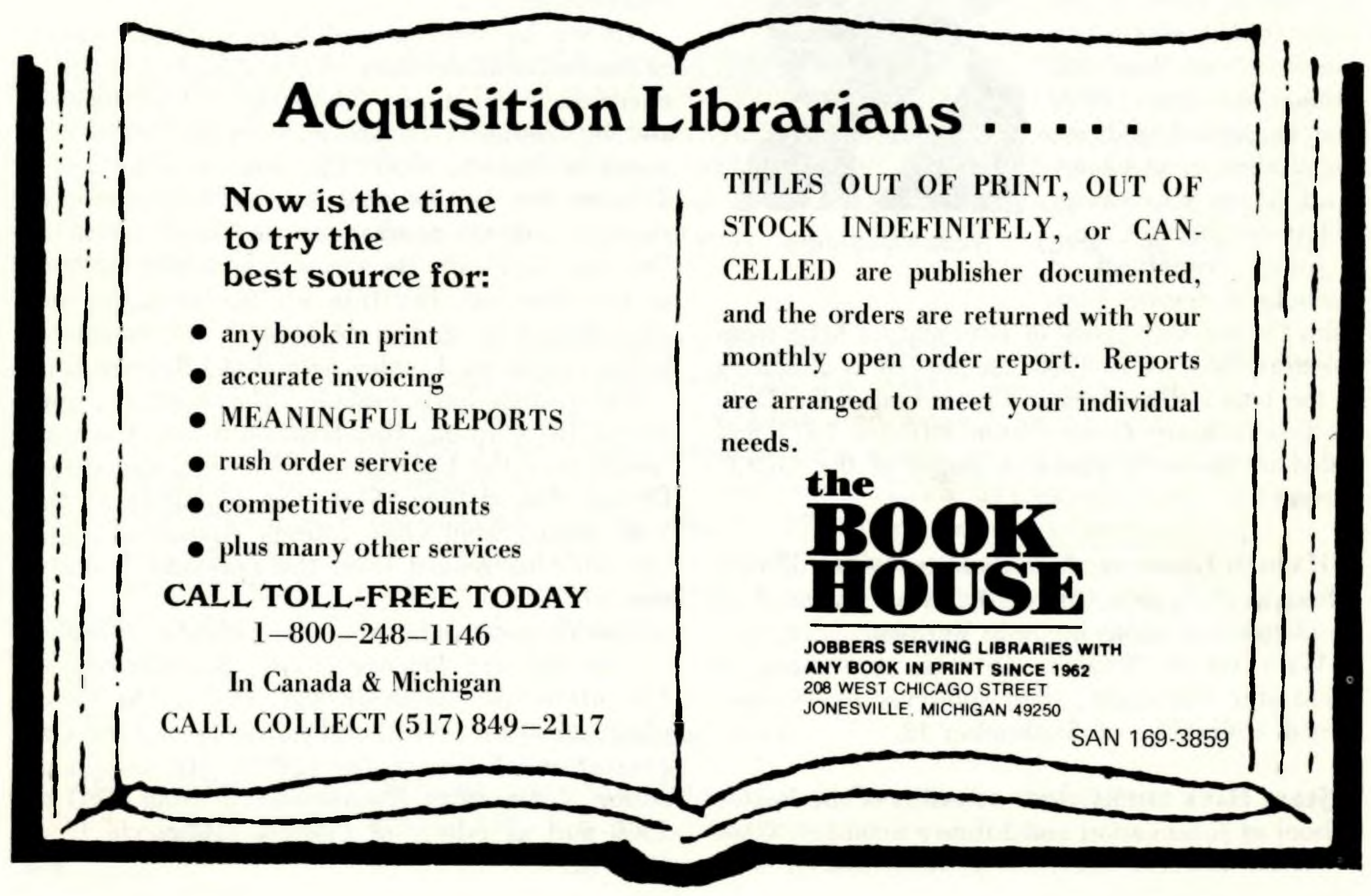




\section{RETIREMENTS}

William H. Bond, librarian of Harvard College's Houghton Library since 1965, will retire on June 1. Bond will continue to teach in Harvard's English Department and will also conduct a seminar on bibliography. Bond was curator of manuscripts at Harvard from 1948 to 1964 , assistant to the librarian at Houghton Library 1946-1948, and research fellow at the Folger Shakespeare Library in 1941-1942. In 1981 he was named Sandars Reader in Bibliography at Cambridge University.

Dorothy Cooke has retired as university librarian at Dalhousie University, Nova Scotia.

\section{DEATHS}

Bogdan Deresiewicz, former rare book cataloger at the University of California, Santa Barbara, died in March.

Dennis Alfred Gibson, reference librarian at the University of Southwestern Louisiana, Lafayette, died on November 8 from injuries he sustained in an automobile accident.

James Victor Jones, director of the Case Western Reserve University Libraries, Cleveland, since 1968, died on February 27. Jones was known nationwide for his expertise in library organization, management, and planning.

From 1955 to 1966 he was director of libraries at Saint Louis University, where he planned the Pius XII Memorial Library. After that he served as director of libraries at Cleveland State University before coming to Case.

Jones received a

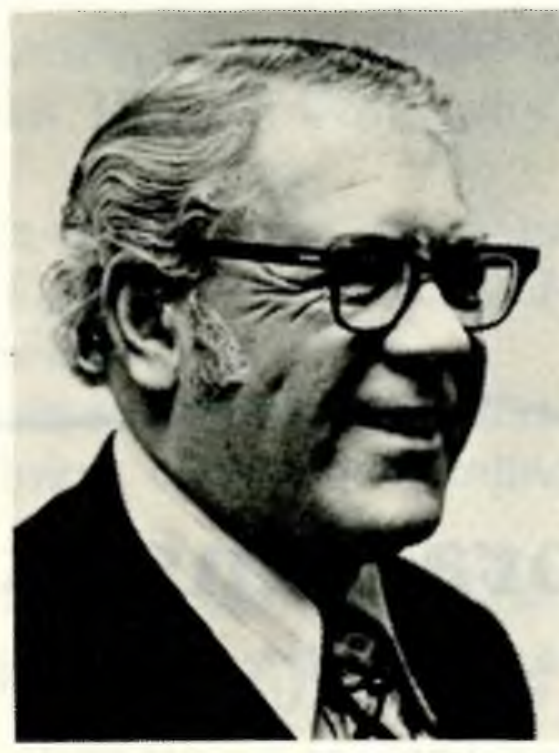

James $V$. Jones bachelor's degree from

John Carroll University in 1949 and an MLS from Western Reserve in 1950. He served as chairman of the board of trustees and president of the Ohio College Library Center from 1971 to 1975 and aided in the early planning stages of the OCLC system.

HAROLd LANCOUR, dean emeritus of the library school at Dalhousie University, Nova Scotia, died on October 23 at his home in Vermont.

William B. Ready, librarian emeritus at McMaster University, died suddenly in Victoria, British Columbia, on September 12.

Jesse Hauk Shera, dean emeritus of the Baxter School of Information and Library Sciences, Case Western Reserve University, died March 8 in
Cleveland at the age of 78. Shera served as dean of the library school from 1952 to 1970 , and established the Center for Documentation and Communication Research there in 1955. Though he was partially blind from birth, he was an acknowledged visionary who saw far into the future of his profession.

Shera's career in li-

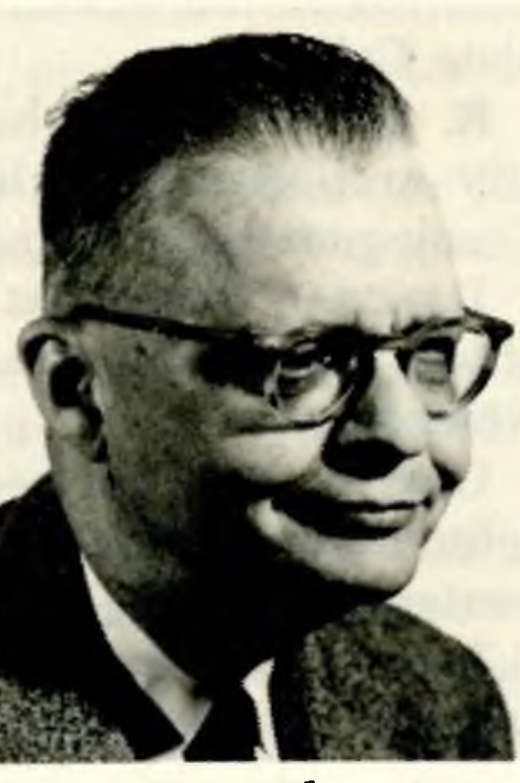

Jesse Shera brary work began in 1927 when he became an assistant to the librarian at Miami University, Oxford, Ohio. The next year he became bibliographer and research associate at the Scripps Foundation for Research in Population Problems. In 1940 he was named chief of the census-library project at the Library of Congress to develop a collection in population and demography. The next year he was appointed deputy chief of the Central Information Division of the Office of Strategic Services. He left in 1944 to become associate librarian at the University of Chicago. In 1947-1952 he was associate professor at the University of Chicago Graduate Library School.

After his retirement from Case Western he served for one year as visiting professor at the Graduate Library School of the University of Texas, returning to Case as dean and professor emeritus in 1972.

Among his international honors, Shera served as international delegate to the UNESCO conferences on International Bibliographic Organization and Bibliographic Organization in the Social Sciences in Paris in 1950. The same year he was a delegate for the National Science Foundation to an international conference on classification at Dorking, England. He was also a visiting lecturer at the Brazilian Institute for Bibliography and Documentation in Rio de Janeiro, at Bangalore, India, and at the London School of Librarianship.

His awards have included the Kat!a, a gold medal from India, the Distinguished Alumnus Award from the University of Chicago, the Melvil Dewey Award from ALA, the Librarian of the Year Award from Ohio Library Association, and the Ohioana Award from the Ohioana Foundation.

Shera's many publications include An Introduction to Library Science (1976), Foundations of Education for Librarianship (1972), The Compleat Librarian (1970), and Libraries and the Organization of Knowledge (1965). He served as editor of American Documentation from 1953 to 1960 and as editor of Library Quarterly from 1947-52. 